\title{
DPSIR conceptual framework role: a case study regarding the threats and conservation measures for caddisflies (Insecta: Trichoptera) in Romania
}

\author{
M. Pîrvu ${ }^{(1), \star}$, M. Petrovici ${ }^{(1)}$
}

Received January 7, 2013

Revised July 13, 2013

Accepted September 6, 2013

Key-words: caddisflies, biodiversity, Natura 2000, DPSIR, Romania

\section{ABSTRACT}

The implementation of some strategies such as DPSIR framework may lead to a better coordination at both local and national level with a view to maintaining biodiversity and quality of water bodies. The different sensibility of the benthic macroinvertebrates has been used in determining the manner in which these communities are being influenced by the socioeconomic development, in the end modifying the biodiversity. The present study aims at presenting a list concerning the different species of caddisflies identified in the larva phase in Natura 2000 site Lower Gorge of Mures river, to draw attention on existing threats regarding the quality of aquatic ecosystems based on the indentified caddisflies species and also to propose a series of conservation measures considered essential to the sustainable development of socio-ecological complexes in the target area. The sample collecting points were represented by 13 stations used to identify the caddisflies species in the larva phase. There were identified 20 species included in a number of 7 families. The most frequent species were Hydropsyche instabilis and Hydropsyche fulvipes (qualitative samples), and Hydropsyche instabilis, Hydropsyche fulvipes and Ecclisopteryx madida (quantitative samples), respectively.

\section{RÉSUMÉ}

Le rôle du cadre conceptuel DPSIR : une étude de cas concernant les menaces et les mesures de conservation pour les trichoptères en Roumanie

Mots-clés : trichoptères, biodiversité, Natura 2000, DPSIR, Roumanie
La mise en œuvre de certaines stratégies telles que le cadre DPSIR peut conduire à une meilleure coordination au niveau local et national en vue de préserver la biodiversité et la qualité des masses d'eau. La sensibilité variable des macroinvertébrés benthiques a été utilisée pour déterminer la manière dont ces communautés sont influencées par le développement socioéconomique, modifiant finalement la biodiversité. La présente étude vise à présenter une liste concernant les différentes espèces de trichoptères identifiés en phase larvaire dans le site Natura 2000 de la partie inférieure des gorges de la rivière Mures, pour attirer l'attention sur les menaces existantes concernant la qualité des écosystèmes aquatiques en fonction des espèces de trichoptères repérées et également de proposer une série de mesures de conservation considérées comme essentielles pour le développement durable des complexes socio-écologiques dans la zone cible. Les points d'échantillonnage

(1) West University of Timişoara, Faculty of Chemistry, Biology, Geography, Department of Biology Chemistry, Pestalozzi 16A, 300115 Timişoara, Romania

* Corresponding author: malina.pirvu@e-uvt.ro 
sont 13 stations utilisées pour identifier les espèces de trichoptères en phase larvaire. On a identifié 20 espèces appartenant à 7 familles. Les espèces les plus fréquentes ont été Hydropsyche instabilis et Hydropsyche fulvipes (échantillons qualitatifs) et Hydropsyche instabilis, Hydropsyche fulvipes et Ecclisopteryx madida (échantillons quantitatifs), respectivement.

\section{INTRODUCTION}

In recent years many alarm signals have warned us on the deterioration of environmental components due to the social and economic developments. Few people have understood the danger of environmental degradation and express concern for the necessity of maintaining the natural balance, water degradation becoming a more and more disputed issue of debate around the world (Tamazian et al., 2009; Acreman and Ferguson, 2010).

Integrated ecological monitoring of aquatic environment quality entails the use of multiple chemical, physical and biological analyses, in addition to the coordinated and sustainable implementation of sustainable strategies. The scientific importance of studying aquatic life is given by the particularities of the aquatic environment where aquatic organisms are adapted to particular habitat conditions (King et al., 2010; Renöfält et al., 2010; Décamps, 2011; Pinto et al., 2011; Gerth et al., 2013).

Furthermore, biodiversity, as the main condition of human civilization, plays a central role in ensuring the life support system as well as the development of social and economic systems. In natural and semi-natural ecosystems the intra and interspecific connections enable the material, energetic and information exchanges and ensure ecosystems productivity, adaptability and resilience. Every species plays a distinct role in the functioning and maintenance of ecological systems as main providers of resources on which human development depends (Xing et al., 2009, Tisdell, 2011, Schetke et al., 2012), the preservation of biodiversity being essential for the survival of all forms of life, including benthic macroinvertebrates as an indisputable trophic link (Azrina et al., 2006; Yoshimura, 2008; Arthington et al., 2010; Ohl et al., 2010).

Beginning with 1992, the European Union has launched the network of nature conservation Natura 2000 in order not only to protect the natural environment but also to preserve the natural richness in the long term (Marcer et al., 2010; Velázquez et al., 2010). The DPSIR framework (Drivers - Pressure - State - Impact - Response) stands for an appropriate framework towards this direction. It has developed as a systems-based approach which captures key relationships between society and the environment, and is regarded as a philosophy for structuring and communicating policy-relevant research about the environment (Borja et al., 2010; Chen et al., 2011; Tscherning et al., 2012). According to this framework, the socio-economic development acts as pressure factor upon the environment and, as a result, its state changes constantly, along with the conditions that ensure the "ecosystems state of health", resource availability, in one word, biodiversity. All these lead to the impact upon human health, which calls for the response from the part of the society with effect on the socio-economic component or directly on the state and causes of impact through remediation action.

The varied sensibility of caddisflies (Insecta: Trichoptera) as well as the anthropic effects, represents an important argument to widely use caddisflies as biological parameters so that aquatic ecosystems might be more appropriately monitored (Kubosova et al., 2010; Li et al., 2010; Varnosfaderany et al., 2010; Thorp and Rogers, 2011; Pîrvu and Pacioglu, 2012; Savić et al., 2013).

Natura 2000 site Lower Gorge of Mureş river (NLGM) is located in the West of Romania. Researchers have not so far carried out studies on the structure of caddisflies community within the boundaries of the site and on the potential threats to this population. This paper aims to complement and extend the research data and bring forward specific measures attempting to improve the aquatic ecosystems conservation schemes across Romania. 


\section{Table I}

The gross domestic product at the national level and in the three target counties according with the RSY (2008), INS (2009).

\begin{tabular}{|l|c|c|c|c|c|c|c|}
\hline Year / Region & 2001 & 2002 & 2003 & 2004 & 2005 & 2006 & 2007 \\
\hline Romania & 116768.7 & 152017.1 & 197427.6 & 247368.0 & 288954.6 & 344650.6 & 416006.8 \\
\hline West & 11223.6 & 14913.4 & 19822.3 & 25254.1 & 29081.7 & 35788.9 & 42995.7 \\
\hline Arad & 2668.7 & 3452.5 & 4591.1 & 6106.3 & 7028.1 & 8406.7 & 10064.4 \\
\hline Hunedoara & 2468.5 & 3303.5 & 4134.3 & 5205.1 & 5791.2 & 6867.1 & 8740.1 \\
\hline Timiş & 4512.5 & 6157.3 & 8381.5 & 10587.9 & 12526.2 & 16069.9 & 18838.0 \\
\hline
\end{tabular}

RSY - Romanian Statistical Yearbook.

INS - National Institute of Statistics.

\section{METHODOLOGY}

\section{> NLGM PHYSICAL CHARACTERISTICS}

The site (total surface of 55.660 ha) covers two hydrographic basins: Mureş and Bega Basin. $77 \%$ of the territory is covered by Mureş Basin (site surface of about 800 ha, average flow rate $-157 \mathrm{~m}^{3} \cdot \mathrm{s}^{-1}$ on entering the site, and $-179 \mathrm{~m}^{3} \cdot \mathrm{s}^{-1}$ on leaving the site, 260 tributary streams with total length of $240 \mathrm{~km}$ ) and $23 \%$ is covered by Bega Basin (site surface of about $45 \mathrm{~km}^{2}, 135$ tributary streams with total length of $115 \mathrm{~km}$ ) (according to the local Management Plan, 2007).

NLGM adjoins with the Natura 2000 site Drocea and with Runcu Groşi Nature Reserve. Mureş corridor, situated in the south of Arad County is a net line between Poiana Rusca Mountains and Lipova Hills to the South and Zărandului Mountains to the north. Its emerging as a separate unit over a long distance of about $70 \mathrm{~km}$, forming a corridor with narrow valleys and basins sectors which shows a very complex morphology (according to the local Management Plan, 2010).

\section{> SOCIO-ECONOMIC CHARACTERISTICS AND INTERACTIONS}

The site is included in one region, namely the West Region of Romania. It spreads across the administrative territory of three counties: Arad, Timiş and Hunedoara (54\% - Arad, 35\% Timiş, $11 \%$ - Hunedoara). It overlaps the administrative territory of 15 localities (towns and villages). 33108 inhabitants live within the site boundaries and in the neighbouring areas, according to the 2002 census (according to Direction of Statistics Arad, Timiş and Deva, 2002).

In order to obtain an overview on the socio-economic status of the area were analyzed the socio-economic situations of each of the component county. In late 2006 in Timiş County for instance, the business environment recorded a massive increase in the number of micro-enterprises and a decrease for the large enterprises. According with the Timiş SocioEconomic Development Agency (TSEDA) the foreign capital invested in Timiş County through participation in the capital of the companies established in the period 1991-2006, amounts to 805 million USD (622 million euros), representing 4.1\% of total foreign investment nationwide (TSEDA-TCC, 2009). Thus, Timiş County ranks 4 th in the country in terms of foreign capital invested and in 2nd place in terms of the number of foreign companies active in late 2006. According to the sources, the situation is similar for the Arad and Hunedoara counties.

Overall, there was a decrease in economic activity in the turnover, indicating changes in the economic structure of the county, and also lower industrial activity in favor of services. It can be observed an increase in activity (and turnover) especially in the construction, transport and transport related activities, wholesale and brokerage services, real estate activities (TSEDA-TCC, 2009). The Western Region is considered to be a growing region with superior economic results, the intra-regional disparities being evident in the three counties (Table I).

According with the West Regional Agency for Development (WRAD) in 2008 the western region recorded a total of 859000 active people, which means a reduction of 112000 compared 


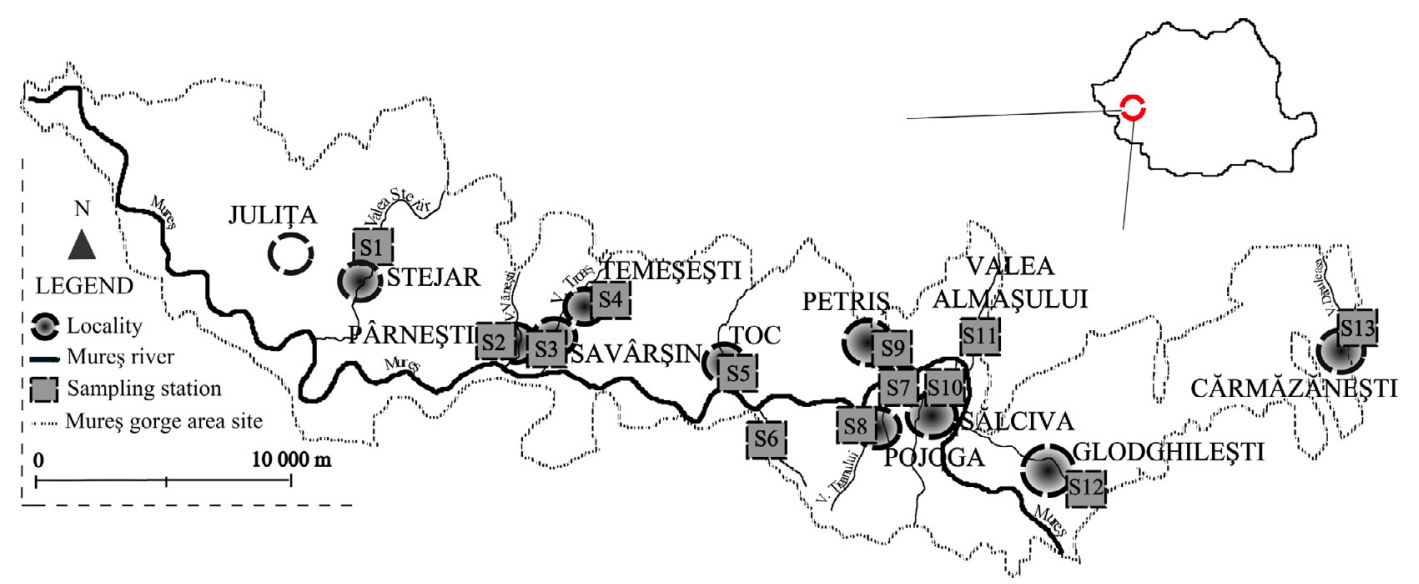

Figure 1

The location of the sample collecting stations from the NLGM, 2010.

to 2000 due to demographic decline. The active population fluctuation and decline, even if it involves a recovery in the range 2006-2007, can be seen in both sexes. The western region also has the largest share of employment in industry. In the case of services, this region has a share of $38.6 \%$ of all employed persons (WRAD, 2009).

Another important social factor is the demographic dependency ratio. Distribution of demographic dependency ratio during 2003-2008 indicates a clear decrease at all levels of analysis (national, regional and county). The lowest economic dependency ratio was found for Timis County in 2008 when there were 37.8 dependents per 100 persons of working age. Another example is the Hunedoara County in the national development (WRAD, 2009).

\section{$>$ MATERIAL AND METHOD}

The samples were collected during June and September of 2010, from the NLGM (13 sampling stations) (Figure 1). Qualitative and quantitative samples were collected. Were processed a total of 13 qualitative samples (1 sample/station) and 39 quantitative samples (3 sam$\mathrm{ples} / \mathrm{station})$. The samples were collected by using a hand net (meshes of $250 \mu \mathrm{m}$ - qualitative samples) and a Surber benthometer (surface of $1072 \mathrm{~cm}^{2}$, dimension of the meshes in the net of $250 \mu \mathrm{m}$ - quantitative samples). The samples were preserved in ethanol $70 \%$. In the laboratory, the identification of the individuals was conducted on a species level (Waringer and Graf, 1997; Wallace et al., 2003). There were not identified those individuals in the first stages of existence at a species level, due to the fact that they did not feature the fully developed morphological traits to allow a proper analysis. In total, a number of 2895 individuals were processed.

\section{> LOCALIZING THE SAMPLING STATIONS AND PROCESSING THE DATA}

The localization of the sampling stations according to the code number is presented in Table II and Figure 1.

The vegetation covering degree was found to be between $0-100 \%$, with average canal depth and width values of $0 \pm 0.03 \mathrm{~cm}$, and $5.42 \pm 2.91 \mathrm{~m}$, respectively.

The sub-layer type corresponding to the benthos sample collecting points varied from the one with a stones, gravel and tamping sand (S1 - S5, S8, S12, S13), to boulders and large amounts of bank (S11), fine gravel and detritus $(\mathrm{S} 9, \mathrm{~S} 10)$ and to the boulders and gravel one (S6, S7).

There have been calculated the density $\left(D_{i}=n_{i} / S_{p}\right)$, the abundance $\left(A=\left(n_{i} / N\right) \times 100\right)$ and the frequency $\left(F=N_{i} \times 100 / N_{p}\right)$, where $n_{i}$ represents the total number of individuals for the $i$ series, 


\section{Table II}

The localization of the sampling stations in NLGM, 2010.

\begin{tabular}{|c|c|c|c|c|}
\hline Sampling stations & Code number & GPS coordinates & Altitude $(\mathrm{m})$ & Observations \\
\hline Stejar Valley & S1 & 46.03368 N $22.154565 \mathrm{E}$ & 158.6 & upstream Stejar village \\
\hline Văneşti Valley & S2 & $46.0305 \mathrm{~N} 22.2221 \mathrm{E}$ & 153 & $\begin{array}{l}\text { upstream Pârneşti } \\
\text { village }\end{array}$ \\
\hline Troaş Valley & S3 & 46.0282 N $22.2517 \mathrm{E}$ & 64 & downstream Săvârşin \\
\hline Troaş Valley & S4 & $46.0418 \mathrm{~N} 22.2643 \mathrm{E}$ & 157.5 & upstream Temeşeşti \\
\hline Crşciunești Valley & S5 & 46.15819 N 22.20237 E & 57 & Toc \\
\hline Duţu rivulet & S6 & 45.9895 N $22.3387 \mathrm{E}$ & 102.9 & Duţu \\
\hline Dinişului rivulet & S7 & $45.5937 \mathrm{~N} 22.2132 \mathrm{E}$ & 101.1 & $\begin{array}{l}\text { tailings heap, } \\
\text { Pojoga quarry }\end{array}$ \\
\hline Tiganului Valley & S8 & 45.9873 N $22.3867 \mathrm{E}$ & 144.4 & $\begin{array}{c}\text { upstream Pojoga } \\
\text { village }\end{array}$ \\
\hline Corbeasca Valley & S9 & $46.0171 \mathrm{~N} 22.3959 \mathrm{E}$ & 144.4 & Petriş \\
\hline Şerban Valley & S10 & $45.9880 \mathrm{~N} 22.4097 \mathrm{E}$ & 133 & $\begin{array}{c}\text { downstream Sălciva } \\
\text { village }\end{array}$ \\
\hline Almaş Valley & S11 & $46.0290 \mathrm{~N} 22.4407 \mathrm{E}$ & 143.9 & Almaş Valley \\
\hline Glodului Valley & S12 & $45.9809 \mathrm{~N} 22.4727 \mathrm{E}$ & 201.5 & $\begin{array}{c}\text { upstream Glodghileşti } \\
\text { village }\end{array}$ \\
\hline Dănuleasca Valley & $\mathrm{S} 13$ & $46.0308 \mathrm{~N} 22.6063 \mathrm{E}$ & 264.7 & Cărmăzăneşti \\
\hline
\end{tabular}

$S_{p}$ the total researched area, $N$ the total number of individuals belonging to all species (from the sample or the studied samples), $N_{i}$ the number of stations within which been identified the subjected species, $N_{p}$ the total number of stations (Stan, 1995). There have been calculated the diversity with Shannon-Wiener (SW) $\left(H^{\prime}=-\Sigma p_{i} \times \log _{2} \times p_{i}\right)$, where $p_{i}$ represents the $i$ series abundance $\left(p_{i}=n_{i} / N\right)$ (Sîrbu and Benedek, 2004). In order to standardize the variation values Pielou's evenness index was further used $\left(E=H^{\prime} / H \max , H \max =\log S\right)$, where $S$ represents the total number of species (Sîrbu and Benedek, 2004).

\section{RESULTS}

\section{> INVENTORY AND DESCRIPTION OF THE POTENTIAL DRIVERS IN THE REGION (D)}

In Table III the two categories of the potential drivers specific to the target area are presented, i.e. natural and anthropogenic drivers. Natural drivers include invasive species that play a key role in altering the integrity of natural terrestrial and aquatic ecosystems specific to the target area, together with factors such as changes in temperature and precipitation regime. Anthropogenic drivers were identified as socially, economically and ecologically/morphologically oriented. Social drivers make direct reference to key elements in ensuring the quality of water bodies, namely the population in the target area and, therefore, urban and rural centers included in the site perimeter (Tables I, III).

The economic drivers were identified as belonging to well developed fields of activity in the area, i.e. agriculture (land cultivation, mowing, orchards, grazing), fishing and hunting, mining, etc. (Table III). The ecological and morphological drivers were considered as follows: inappropriate tourism, household wastes deposit sites commonly found in industrialized and populated areas, activities such as damming, drainage, draining, etc. (Table III).

\section{> ENVIRONMENTAL PRESSURES IN THE TARGED AREA (P)}

The study carried out within the site area has highlighted a series of threats to caddisflies populations among which we underscore: rivers modification and rectification works the present 
Table III

Main categories of drivers identified in NLGM, 2010 (according to the local Management Plan, 2007).

\begin{tabular}{|c|c|c|c|}
\hline Driver category & Quantification & Data sources & $\begin{array}{c}\text { Activity code } \\
\text { according } \\
\text { to ESF }\end{array}$ \\
\hline land cultivation & 7.380 ha and thousands of owners & Agricultural agencies & 100 \\
\hline mowing & 920 ha & Agricultural agencies & 102 \\
\hline orchards & 60 ha & Agricultural agencies & 190 \\
\hline grazing & 2780 ha & Agricultural agencies & 140 \\
\hline forestry & 38600 ha & Forest agencies & 160 \\
\hline $\begin{array}{l}\text { forest explotation - } \\
\text { no forestation }\end{array}$ & in private forests & $\begin{array}{l}\text { Forestry and Hunting } \\
\text { Inspectorate }\end{array}$ & 167 \\
\hline mineral extraction & $\begin{array}{l}2 \text { gravel pits inside the site } \\
\text { and } 1 \text { by Mureş river }\end{array}$ & $\begin{array}{l}\text { National Administration } \\
\text { of Romanian Waters }\end{array}$ & 300 \\
\hline quarry & $\begin{array}{c}2 \text { gravel quarry at Pojoga } \\
\text { and Căprioara }\end{array}$ & $\begin{array}{c}\text { National Agency } \\
\text { of Mineral Resources }\end{array}$ & 301 \\
\hline mining activities & $\begin{array}{l}\text { mining extraction } \\
\text { upstream the site }\end{array}$ & $\begin{array}{c}\text { National Agency } \\
\text { of Mineral Resources }\end{array}$ & 331 \\
\hline urban/rural areas & $\begin{array}{c}13 \text { localities/ } \\
\text { 33. } 108 \text { inhabitants }\end{array}$ & $\begin{array}{c}\text { Local councils, } \\
\text { County Statistics Agencies }\end{array}$ & 400 \\
\hline water pollution & $\begin{array}{l}\text { in all localities inside and outside } \\
\text { the site/refuse, tailings heap }\end{array}$ & Field observations & 701 \\
\hline $\begin{array}{l}\text { drainage, damming, } \\
\text { draining }\end{array}$ & $\begin{array}{l}\text { past drainage, damming or draining } \\
\text { led to diminishing humid areas }\end{array}$ & $\begin{array}{l}\text { National Administration } \\
\text { of Romanian Waters }\end{array}$ & $800 / 803 / 810$ \\
\hline species invasion & $\begin{array}{c}\text { Acer negundo } \\
\text { and Amorpha fruticosa }\end{array}$ & Forest agencies & 954 \\
\hline tourism & travel pass & field observations & 623 \\
\hline
\end{tabular}

ESF - European Social Fund.

study identified on Chiciura and Juliţa river valleys, sand and gravel extraction observed on Juliţa and Vâneşti river valleys, modifications observed in the major and minor bed of the water bodies monitored, deforestation of riparian vegetation on Şerban and Juliţa river valleys, together with accumulation of household waste along many rivers (Stejar, Chiciura, Troaş, Juliţa, Glodului), mining activities (upstream the site), gravel quarries (Pojoga and Cãprioara), mineral extraction (there are two gravel pits inside the site and 1 by Mureş river, close to the site), urbanism (13 localities are included in site area, which means about 10.000 inhabitants), damming (several hundred meters) (Figure 1).

\section{> THE AQUATIC ECOSYSTEM STATUS IN THE TARGET AREA USING CADDISFLIES AS BIOLOGICAL INDICATORS (S)}

\section{Caddisflies community structure}

After processing the samples, the following caddisfly species were identified:

Qualitative samples: there were identified 6 genera included in a number of 4 families: Fam. Hydropsychidae: genus Hydropsyche $(H$. angustipennis Curtis $1834, H$. fulvipes Curtis 1834 , H. instabilis Curtis 1834, H. incognita Pitsch 1993, H. pellucidula Curtis 1834), Fam. Polycentropodidae: genus Polycentropus (PI. flavomaculatus Pictet 1834), Fam. Limnephilidae: genus Limnephilus (L. affinis Curtis 1834, L. rhombicus Linnaeus 1758), genus Potamophylax (P. latipennis Curtis 1834, P. rotundipennis Brauer 1857, P. nigricornis Pictet 1834) Fam. Phryganeidae: genus Hagenella (H. clathrata Kolenati 1848), genus Halesus (HI. digitatus von Paula Schranch 1781), Fam. Rhyacophilidae: genus Rhyacophila (R. fasciata Hagen 1859). The Hydropsyche featured the highest number of species (5), followed by the rest of the types, with one to three species each. Their distribution according to the sample collection stations and species code is shown in Table IV. 


\section{Table IV}

Caddisflies species distribution (qualitative samples) in NLGM, 2010.

\begin{tabular}{|c|c|c|c|c|c|c|c|c|c|c|c|c|c|c|}
\hline & SC & S1 & 52 & 53 & 54 & 55 & 56 & S7 & 58 & 59 & 510 & S11 & S12 & $\mathrm{S13}$ \\
\hline H. angustipennis & H. a. & & & & $\mathrm{x}$ & & & & $\mathrm{x}$ & & & & & \\
\hline H. fulvipes & H. f. & & $x$ & & & $x$ & $x$ & $x$ & $\mathrm{x}$ & & $x$ & $x$ & & $x$ \\
\hline H. instabilis & H. ins. & $x$ & $x$ & $x$ & $\mathrm{x}$ & $\mathrm{x}$ & & $\mathrm{x}$ & $\mathrm{x}$ & & $x$ & $x$ & $x$ & $x$ \\
\hline H. incognita & H. inc. & & & $x$ & $\mathrm{x}$ & & & & & & & & & \\
\hline H. pellucidula & H. p. & & & & & & & & $\mathrm{x}$ & & & $x$ & & $x$ \\
\hline PI. flavomaculatus & PI. f. & & & & & & $x$ & & & & & & & \\
\hline L. affinis & L. a. & $\mathrm{x}$ & & & & & & & & & & & & \\
\hline L. rhombicus & L. $r$. & & & & & & $x$ & & & & & & & \\
\hline P. latipennis & P. I. & $\mathrm{x}$ & $\mathrm{x}$ & & & $x$ & & $x$ & & & & $x$ & & \\
\hline$P$. rotundipennis & P. r. & & & & & & $x$ & & $\mathrm{x}$ & & & & & \\
\hline P. nigricornis & P. n. & & & & & & $x$ & & & & & $x$ & & \\
\hline HI. digitatus & HI. d. & & & & & $x$ & & & & & & & & \\
\hline R. fasciata & R. f. & & & & $x$ & $x$ & & & & & & & & \\
\hline
\end{tabular}

The $x$ sign indicates the presence of the species; SC - species code.

The main caddisfly species identified in this phase together with the numeric abundance percentages (\%) and the frequency values were shown in Figure 2.

As far as frequency is concerned, the $H$. instabilis species values remained highest $(82.62 \%)$, followed by $H$. fulvipes (61.54\%), as opposed to the remaining species whose frequency did not exceed $16 \%$ with a few exceptions: $H$. angustipennis and $H$. pellucidula (23.08\%). The lowest values were identified as belonging to 5 species, with a frequency value of $7.69 \%$ each (Figure 2A).

The numerical abundance percentages have shown high values for 2 species belonging to genus Hydropsyche $(H$. instabilis $-41.07 \%, H$. fulvipes $-21.79 \%)$ and a species belonging to genus Potamophylax (P. latipennis $-17.71 \%$ ), the rest of the values ranging from $0.31 \%$ (L. rhombicus) to $6.90 \%$ (H. pellucidula) (Figure $2 \mathrm{~B}$ ).

Quantitative samples: there were identified 9 genera included in 7 families: Fam. Leptoceridae: genus Athripsodes (Ath. bilineatus Linnaeus 1758), Fam. Hydropsychidae: genus Hydropsyche $(H$. angustipennis Curtis $1834, H$. fulvipes Curtis $1834, H$. instabilis Curtis 1834 , H. pellucidula Curtis 1834), genus Cheumatopsyche (C. lepida Pictet 1834), Fam. Limnephilidae: genus Limnephilus (L. affinis Curtis 1834, L. rhombicus Linnaeus 1758), genus Ecclisopteryx (E. madida McLachlan 1867), Fam. Polycentropodidae: genus Polycentropus (PI. flavomaculatus Pictet 1834), Fam. Rhyacophilidae: genus Rhyacophila ( $R$. fasciata Hagen 1859, R. dorsalis Curtis 1834, R. obliterata McLachlan 1863), Fam. Goeridae: genus Silo (SI. nigricornis Pictet 1834), Fam. Sericostomatidae: genus Sericostoma (S. personatum Kirby and Spence 1826).

The most numerous species were identified for genera Rhyacophila and Hydropsyche, with 4 and 3 species respectively. Their distribution according to the sample collection stations and species code was shown in Table V.

The main caddisfly species identified in the quantitative samples together with the average density values (ind $\mathrm{m}^{2-1}$ ), the numeric abundance percentages (\%) and the frequency values were shown in Figure 3.

The frequency (\%) shows maximum values for a great number of species (6), while the rest of the species identified in the LMNP in the current study accumulated values of $2.56 \%$ each (Figure 3A).

The collected quantitative samples showed a high numerical abundance percentage (\%) for 3 of the 15 species identified in the current study $(H$. instabilis $-44.66 \%$, H. fulvipes $-19.76 \%$ and $E$. madida with values of $8.43 \%)$. The smallest numerical abundance percentages $(0.53 \%)$ were established for 2 of 15 species (R. dorsalis, L. rhombicus) (Figure 3B).

When calculating the average density ( $L C=$ the confidence limit at $0.05 p$ ) there were noticed high values for the 3 species mentioned earlier, with a maximum of 81.01 ind $\mathrm{m}^{2-1}$ for 


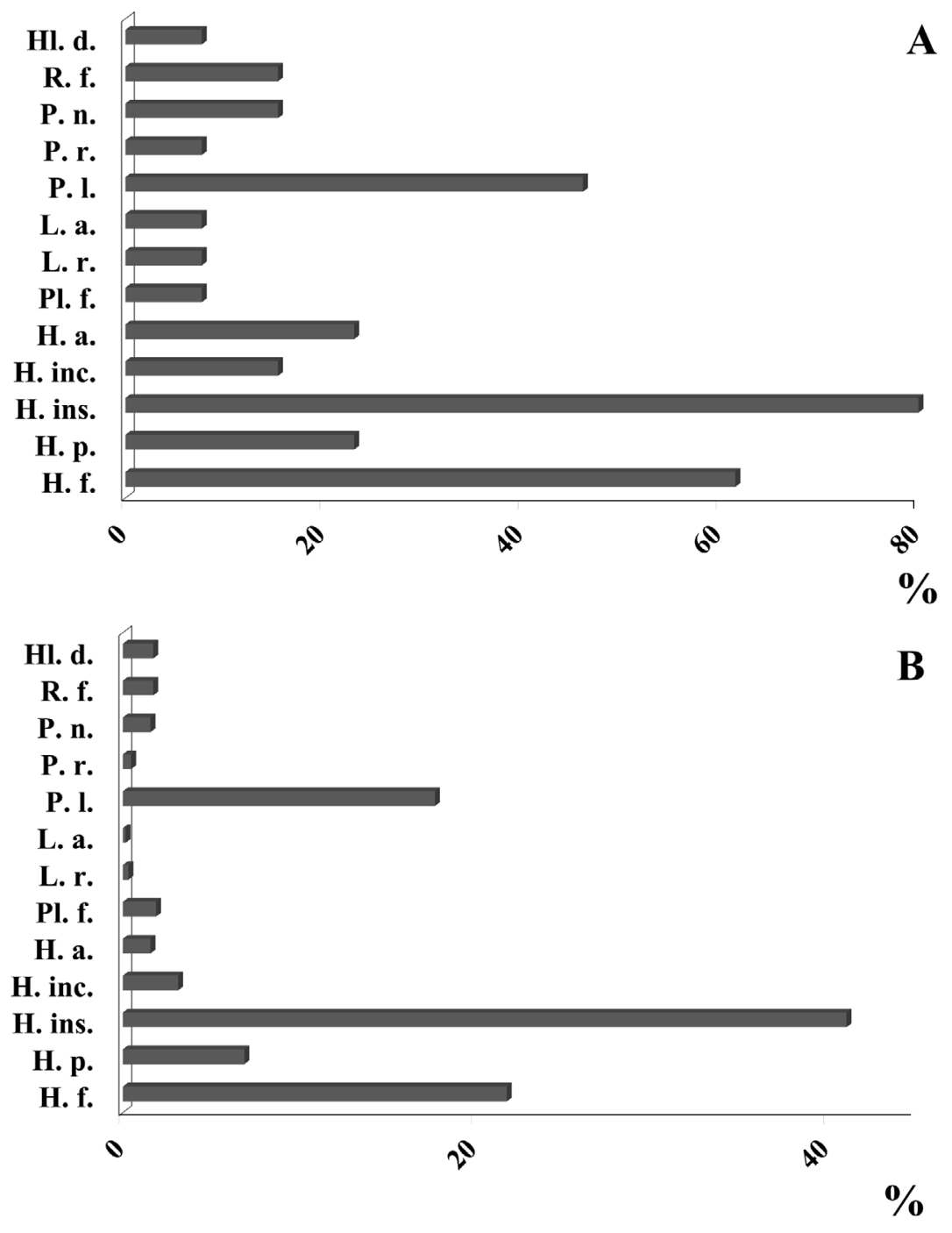

Figure 2

Frequency - \% - (A) and percentage numerical abundance - \% (B) (qualitative samples) in NLGM, 2010.

\section{Table $\mathrm{V}$}

Caddisflies species distribution (quantitative samples) in NLGM, 2010.

\begin{tabular}{|c|c|c|c|c|c|c|c|c|c|c|c|c|c|c|}
\hline & SC & S1 & S2 & S3 & 54 & 55 & S6 & 57 & 58 & S9 & 510 & S11 & S12 & $S 13$ \\
\hline H. angustipennis & H. a. & & & & & & $x$ & & & & & & & \\
\hline H. fulvipes & H.f. & $\mathrm{X}$ & $x$ & & $x$ & $\mathrm{x}$ & & $\mathrm{x}$ & $x$ & $\mathrm{x}$ & & & & \\
\hline H. instabilis & H. ins. & $\mathrm{X}$ & $x$ & & $\mathrm{x}$ & $\mathrm{x}$ & & $\mathrm{x}$ & $\mathrm{x}$ & $\mathrm{x}$ & $x$ & $\mathrm{x}$ & $x$ & \\
\hline H. pellucidula & H. p. & & & & $x$ & & & & & & & & & \\
\hline C. lepida & C.I. & & $x$ & & & & & & & & & & & \\
\hline PI. flavomaculatus & PI. f. & & & & & & $x$ & & & & & & & \\
\hline L. affinis & L. a. & & & & & & & & & $\mathrm{x}$ & & & $\mathrm{x}$ & \\
\hline L. rhombicus & L. $r$. & & & & & & & & & $\mathrm{x}$ & & & & \\
\hline E. madida & E. $m$. & & & $x$ & & & $x$ & & & & & & & $x$ \\
\hline S. personatum & S. p. & & & $x$ & & & & & & & & & & \\
\hline A. bilineatus & A. b. & & & & & & & & & & & & & $\mathrm{x}$ \\
\hline Sl. nigricornis & SI. n. & & & & & & & & & & & & $\mathrm{x}$ & $x$ \\
\hline R. fasciata & R.f. & & & & & $x$ & $x$ & & & & & & & $x$ \\
\hline R. dorsalis & R. d. & & & & & & & & & & & $x$ & & \\
\hline R. obliterata & R. O. & & & & & & & & & & $x$ & & & \\
\hline
\end{tabular}

the $x$ sign indicates the presence of the species; SC - species code. 

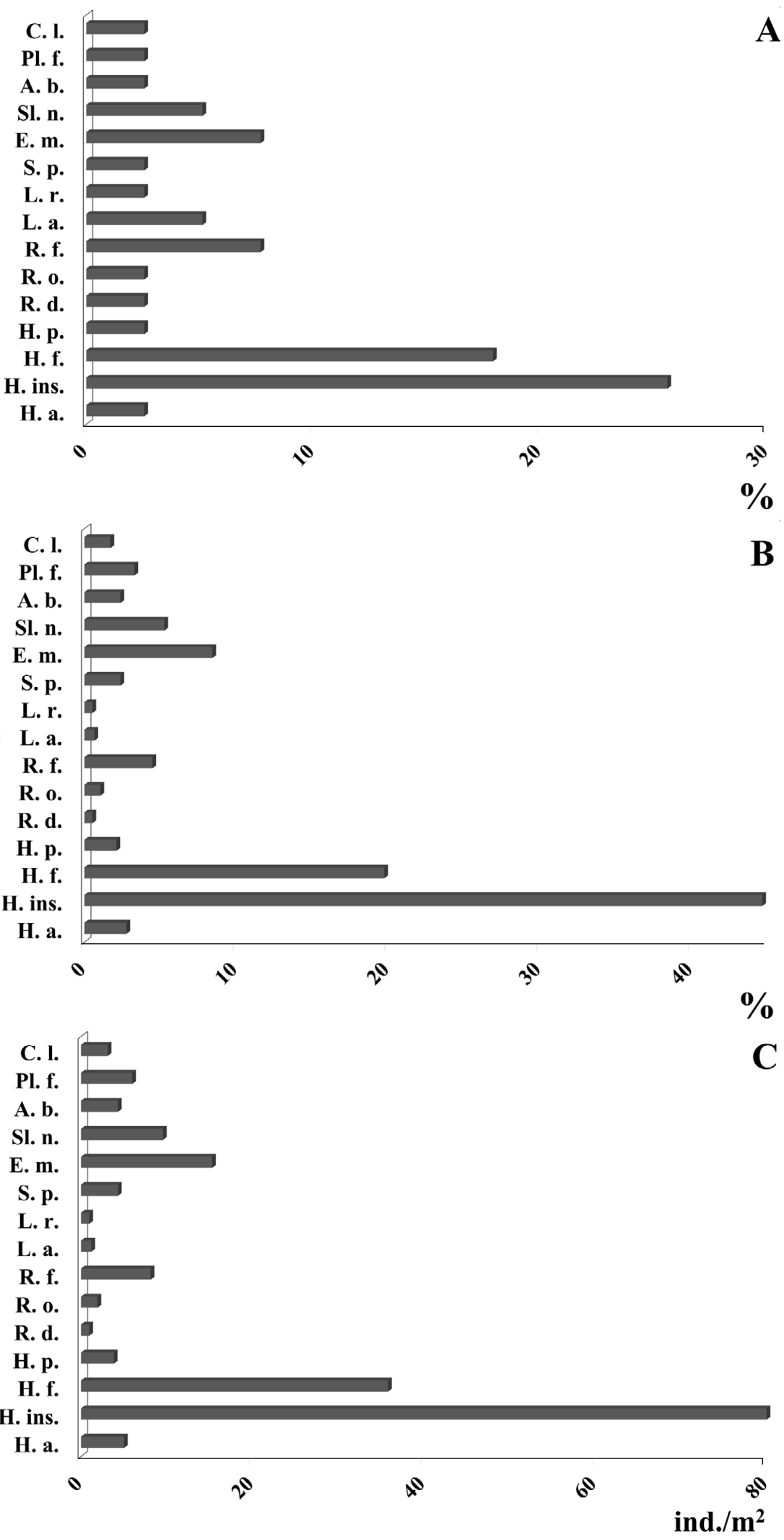

Figure 3

Frequency - \% - (A), percentage numerical abundance - \% - (B) and average density - ind $m^{2-1}-(C)$ of caddisflies species (quantitative samples) in NLGM, 2010. 


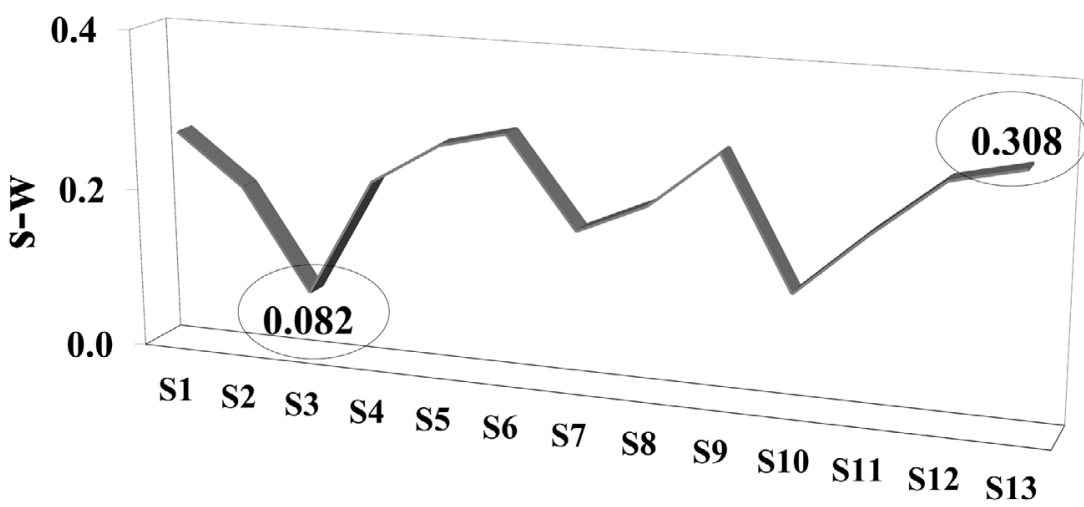

Figure 4

Average values of SW index regarding the caddisflies species identified within the NLGM area, 2010.

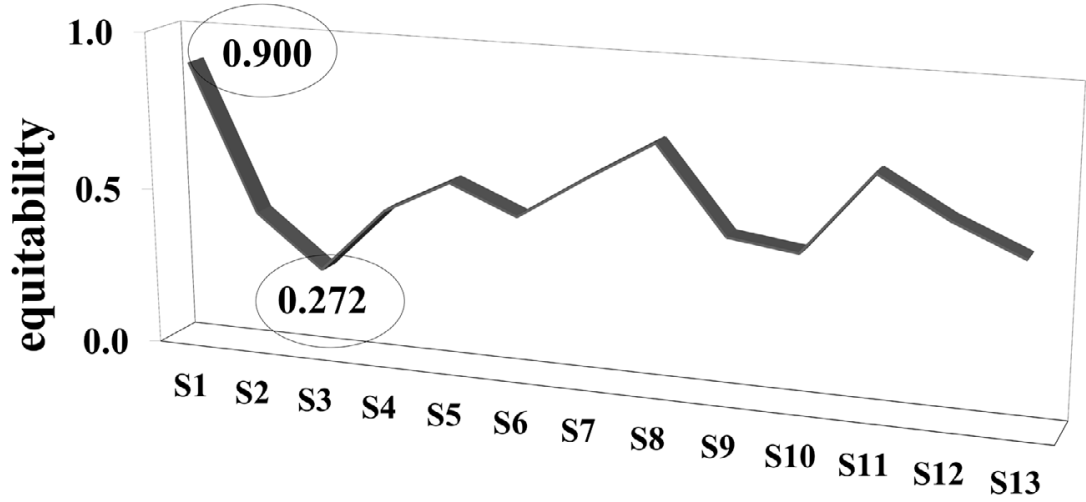

Figure 5

Average values of the equitability indices regarding the caddisflies species identified within the NLGM area, 2010.

$H$. instabilis, followed by $H$. fulvipes (35.84 ind $\mathrm{m}^{2-1}$ ) and $E$. madida $\left(15.29\right.$ ind $\left.\mathrm{m}^{2-1}\right)$. The smallest value was established as belonging to the $R$. dorsalis $\left(0.96\right.$ ind $\left.\mathrm{m}^{2-1}\right)$ (Figure $\left.3 \mathrm{C}\right)$.

\section{Caddisflies diversity in the targed area}

The lowest values of Shannon-Wiener index (SW) regarding the structure of caddisflies community submitted to study were identified at station S3 (0.082), collection point characterized by a series of threats such as significant quantities of waste in the bed river, followed by station S10 (0.141) where high pressures were recorded due to frequent domestic waste accumulations (plastic, metal, bottles, etc.), in the river bed and on the riparian vegetation, and station S7 (0.191) located in the vicinity of a tailings heap.

Maximum values of caddisflies species diversity were determined for station S13 (0.308), ecosystem characterized by a natural aspect, without visible or potential threats, and station S6 (0.301) (Figure 4). For evenness purposes, similar values may be due to the occurrence of many common species, or on the contrary, the values may be specific to each station, characterized by a reduced number of individuals. This is the case of a large number of species $(H$. pellucidula, $H$. angustipennis, $R$. obliterata, L. rhombicus, A. bilineatus, Pol. flavomaculatus and C. lepida) identified only at certain control points and represented by a small number of individuals (Figure 5). 


\section{> IMPACTS ASSESSMENT (I)}

The presence of some species with high tolerance to changes in water quality parameters, such as those belonging to genus Hydropsyche, indicates the occurrence and spread of these threats to the health of the entire aquatic system of the area. Actually, the importance of caddisflies species was recognized not only from the trophic perspective but also due to the fact that the presence, absence or any changes in population size are important parameters in assessing the ecological state of water bodies (Camargo et al., 2011; Simanonok et al., 2011; Wildsmith et al., 2011).

\section{$>$ RESPONSES (R)}

The modification of water quality parameters on account of the uncontrolled actions of these drivers may leave a mark on the natural capital structure and functions in the target area, the decrease of biological diversity in aquatic communities being supported by seemingly unimportant communities such as caddisflies. The identification of a large number of species resistant to pollution in many sectors monitored in this study is a further proof to the study results (see discussions).

\section{DISCUSSIONS}

Water quality monitoring programs are becoming an increasingly important preoccupation in most European countries, as elsewhere in the world, each one using its own or a similar system, the common element being the benthic macrofauna, commonly used as indicator. Since 2000, a new EU Water Framework Directive was adopted setting the objectives for water protection for the future, one of the most important objectives including benthic invertebrates protection as essential trophic link in aquatic ecosystems (Sundermann et al., 2008).

Given the considerable stretch of the site, it is absolutely essential to adopt sustainable management measures in order to support the conservation of biological diversity in the area with the aim of protecting natural aquatic ecosystems and ecological environments in correlation with human activities specific to the target area. Like other species belonging to this genus, $H$. instabilis is a filter-type species as it sometimes find food by capturing the prey; it also shows preference for the sub-layer which consists mainly of fine detritus (Graf et al., 2008). The high values of percentage numerical abundance along with the maximum frequency $(84.62 \%)$ identified in the samples collected indicate high adaptability to different habitat conditions (Mobes-Hansen and Waringer, 1998; González et al., 2002; Argerich et al., 2004; Jović et al., 2006; Durance and Ormerod, 2007). The larvae of the $H$. instabilis species is being generally tolerating when the qualitative parameters of the aquatic eco-systems change (Graf et al., 2008). Inside the NLGM, it was identified in 10 locations (Tables IV, V).

The second highly abundant species ( $H$. fulvipes) can be described as being specific for the spring brooks and as well for the upper trout region, at an altitude of more than $1500 \mathrm{~m}$, and below $150 \mathrm{~m}$, along the main channel and connected side arms (Wallace, 1990; Graf et al., 1995; 2002; Malicky, 2008). It is usually found in streams with high preference for slowly flowing streams and lentic zones (Graf et al., 2008). In the present study, it was identified in the samples collected from 7 stations (Table IV, V). The two species of genus Hydropsyche $(H$. instabilis and $H$. fulvipes) are generally characteristic for the lotic eco-systems whose speed can vary from moderate to high, although their high tolerance to the water quality may suggest a large distribution (Admiraal et al., 2000; Bonada et al., 2004; Brunke, 2004).

Establishing maximum percentage numerical abundance values for the same two aforementioned species shows, in case of quantitative sampling as well, low sensitivity and high adaptability of these species to habitat conditions (Lukáš and Krno, 2003; Kazanciand and Dügel, 2008). Actually, numerous studies have included the two species in the category of those species that are not influenced by changes in parameters such as $\mathrm{pH}$, oxygen concentration 


\begin{tabular}{|c|c|c|}
\hline $\begin{array}{l}\text { DRIVING } \\
\text { FORCES }\end{array}$ & \multicolumn{2}{|c|}{$\begin{array}{l}\text { - sectors/sourses of importance, agriculture, forestry, rural } \\
\text { development industry, structure and production results, } \\
\text { consumption }\end{array}$} \\
\hline PRESSURE & \multicolumn{2}{|l|}{ - emissions, resourse use } \\
\hline \multirow[t]{3}{*}{ STATE } & $\begin{array}{c}\text { Factors of a physical } \\
\text { nature }\end{array}$ & $\begin{array}{l}\text { - hydrology of the area } \\
\text { - accessibility of resourses }\end{array}$ \\
\hline & $\begin{array}{c}\text { Factors of a chemical } \\
\text { nature }\end{array}$ & - quality of aquatic ecosystems \\
\hline & $\begin{array}{c}\text { Biological/ecological } \\
\text { factors }\end{array}$ & $\begin{array}{l}\text { - species diversity of the target } \\
\text { area }\end{array}$ \\
\hline IMPACT & \multicolumn{2}{|c|}{$\begin{array}{l}\text { - environmental and economic impact in the function of } \\
\text { aquatic ecosystems } \\
\text { - simplification of the structure and functions of the } \\
\text { natural capital } \\
\text { - impacts on human health and on the economic and social } \\
\text { performance of the society }\end{array}$} \\
\hline RESPONSE & \multicolumn{2}{|c|}{$\begin{array}{l}\text { - setting priorities and objectives persued } \\
\text { - measures at macroeconomic level } \\
\text { - environmental strategies }\end{array}$} \\
\hline
\end{tabular}

Figure 6

DPSIR framework structure proposed for NLGM, 2010.

in water, pollution (Braukmann and Biss, 2004; Pastuchová, 2006; Graf et al., 2008; Schmeraa and Erös, 2011). With a distribution and a preference different for genus habitat, E. madida can frequently be found at altitudes between 1500 and $300 \mathrm{~m}$ in upper and lower trout region also (Graf et al., 2008; Paulsa et al., 2008; Schmeraa and Erös, 2011). In contrast, species of genus Rhyacophila were identified as having the lowest values, the 3 species being generally conditioned by physical and chemical parameters, particularly for waters with low temperature, high flow rate and a sub-layer made up mainly of gravels (Langheinrich et al., 2002; Bonada et al., 2004; Hildrew, 2009).

The large part of the caddisfly species are potamobiont, although the diversity of the microhabitats allows even the presence of those species such as $A$. bilineatus which is a species with a wider ecological spectrum. As a consequence, caddisflies were chosen as bioindicators because this insect order has evolved a wide range of physiological, behavioural and morphological adaptations, allowing them to colonise a variety of aquatic ecosystems (Al-Shami et al., 2011; Ruiz-García et al., 2012). In addition to their function as biological indicators, the importance of these organisms is given by both their practical and theoretical role. From a practical point of view, the adult individuals but especially larvae, are particularly important to pisciculture, as main link in trophic chain (Hershey et al., 2007; Winkelmann et al., 2007). Similarly, trichoptera larvae consume decomposing organic substances and thus, they contribute to cleaning waters (Lepneva, 1970). From a theoretical point of view, caddisflies provide data particularly for phylogenetic and zoogeographical researches (Lepneva, 1970).

Low diversity identified in the study area may be considered as a feature of a stressed biocoenosis that tends to be unstable, instability which is finally felt at the level of all trophic links of the particular ecosystem (Figures 4, 5). NLGM was identified as a complex system including economic, social and environmental factors (Table I, III). The way biodiversity of aquatic ecosystems is perceived, along with the implementation of inefficient management measures at local level, feasible only for a short period of time, led to the growth of the effects various factors have upon aquatic communities such as caddisflies in the target area.

In the long term, the drivers and pressures identified in the target area may lead to the erosion of biological biodiversity and the extinction of some species and taxa, loss of genetic resources, increase of rare or threatened species. Considering all these elements, including the analysis and synthesis of data identified in the study area, we have proposed a DPSIR framework structure suitable for the approached study case (Figure 6). 
Taking into account the main drivers and pressures identified in this study, we bring solid arguments that support the need to track closely this process in the future in order to establish a sustainable control program management transferable to other geographic areas worldwide:

1 Ensuring a high level of public awareness with regard to the need to maintain the security of water bodies so that water quality might be maintained through management measures and policies taken to support sustainable development at local and national level, with potential consequences at global level.

2 Coordinating governmental agencies, local authorities and communities, corroborated with a multidisciplinary approach taken by academic and administrative structures and various stakeholders.

3 Maintaining the quality parameters of water bodies by prohibiting the discharge of untreated domestic wastewater or of any type of waste into the river beds.

4 Prohibiting activities such as deforestation of riparian vegetation and sub-layer extraction from river beds, as well as strictly controlling hydraulic works preventing changes to habitat characteristics.

5 Avoiding the application of sustainable management measures for a short period of time in a fragmented (local) way without implications at a large spatial-temporal scale.

\section{CONCLUSIONS}

A number of 20 caddisfly species was identified across the NLGM (2010).

For the qualitative samples, the highest numerical abundance percentages and frequency were established for 2 of the 20 species which had been identified (Hydropsyche instabilis, Hydropsyche fulvipes). The lowest values were identified for a several species among them species of genus Potamophylax.

For the quatitative samples, values of $25.64 \%$ frequency were noticed in 1 of the 20 species, while the remaining registered values between 17.95 and $5.13 \%$. The highest values of the numerical abundance percentages and average density were established for 2 species mentioned above (Hydropsyche instabilis and Hydropsyche fulvipes).

The application of viable management measures for a long period of time at local, regional and national level, including sustainable development and appropriate education may contribute to improving the quality of aquatic ecosystems as well as the quality of life now and in the future.

\section{REFERENCES}

Acreman M.C. and Ferguson A.J.D., 2010. Environmental flows and the European Water Framework Directive. Fresh. Biol., 55, 32-48.

Admiraal W., Barranguet C., van Beusekom S.A.M., Bleeker E.A.J., van den Ende F.P., van der Geest H.G., Groenendijk D., Ivorra N., Kraak M.H.S. and Stuijfzand S.C., 2000. Linking ecological and ecotoxicological techniques to support river rehabilitation. Chemosphere, 41, 289-295.

Al-Shami S.A., Rawi C.S.M., Ahmad A.H., Hamid S.A. and Nor S.A.M., 2011. Influence of agricultural, industrial and anthropogenic stresses on the distribution and diversity of macroinvertebrates in Juru River Basin, Penang, Malaysia. Ecotoxicology and Environmental Safety, 74, 1195-1202.

Argerich A., Puig M.A. and Pupilli E., 2004. Effect of floods of different magnitude on the macroinvertebrate communities of Matarranya stream (Ebro river basin, NE Spain). Limnetica, 23, 283-294.

Arthington A.H., Robert J.N., Michael E.M. and Christer N., 2010. Preserving the biodiversity and ecological services of rivers: new challenges and research opportunities. Fresh. Biol., 55, 1-16.

Assogbadjo A.E., Glèlè Kakaï R., Vodouhê F.G., Djagoun C.A.M.S., Codjia J.T.C. and Sinsin B., 2012. Biodiversity and socioeconomic factors supporting farmers' choice of wild edible trees in the agroforestry systems of Benin (West Africa). Forest Policy and Economics, 14, 41-49. 
Azrina M.Z., Yap C.K., Ismail A.R., Ismail A. and Tan S.G., 2006. Anthropogenic impacts on the distribution and biodiversity of benthic macroinvertebrates and water quality of the Langat River, Peninsular Malaysia. Ecotoxicology and Environmental Safety, 64, 337-347.

Bonada N., Zamora-Muñoz C., Rieradevalla M. and Prat N., 2004. Ecological profiles of caddisfly larvae in Mediterranean streams: implications for bioassessment methods. Environmental Pollution, 132, 509-521.

Borja Á., Elliott M., Carstensen J., Heiskanen A.S. and van de Bund W., 2010. Marine management Towards an integrated implementation of the European Marine Strategy Framework and the Water Framework Directives. Marine Pollution Bulletin, 60, 2175-2186.

Braukmann U. and Biss R., 2004. Conceptual study - An improved method to assess acidification in German streams by using benthic macroinvertebrates. Limnologica Ecology and Management of Inland Waters, 34, 433-450.

Brunke M., 2004. Stream typology and lake outlets - a perspective towards validation and assessment from northern Germany (Schleswig-Holstein). Limnologica Ecology and Management of Inland Waters, 34, 460-478.

Camargo J.A., Gonzalo C. and Alonso Á., 2011. Assessing trout farm pollution by biological metrics and indices based on aquatic macrophytes and benthic macroinvertebrates: A case study. Ecological Indicators, 11, 911-917.

Chen C.H., Liu W.L.and Liaw S.L., 2011. Integrated dynamic policy management methodology and system for strategic environmental assessment of golf course installation policy in Taiwan. Environmental Impact Assessment Review, 31, 66-76.

Décamps H., 2011. River networks as biodiversity hotlines. Comptes Rendus Biologies, 334, 420-234.

Direction of Statistics Arad, Timiş Deva, 2002. According to the Natura 2000 Management Plan - Mureş Lower Gorge and Lipovei Hills - RO SPA0029 [in Romanian].

Durance I. and Ormerod S.J., 2007. Climate change effects on upland stream macroinvertebrates over a 25-year period. Global Change Biology, 13, 942-957.

Gerth W.J., Herlihy A.T., Sifneos J.C., 2013. Large-scale macroinvertebrate assemblage patterns from least-disturbed wadeable stream sites across the 48 contiguous US states. Knowledge and Management of Aquatic Ecosystems, 408, 02.

González J.M., Basaguren A. and Pozo J., 2002. Size-mass relationships of stream invertebrates in a northern Spain stream. Hydrobiologia, 489, 131-137.

Graf W., Grasser U. and Waringer J., 1995. [Trichoptera]. Bundesministerium für Land-und Forstwirtschaft, Wien, 280 p. [in German].

Graf W., Grasser U. and Waringer J., 2002. [Trichoptera]. Wasserwirtschaftskataster, Bundesministerium für Land - und Forstwirtschaft, Wien, 388 p. [in German].

Graf W., Murphy J., Dahl J., Zamora-Muñoz C. and López-Rodríguez M.J., 2008. Distribution and ecological preferences of european freshwater organisms - Trichoptera. Pensoft, Bulgaria, $230 \mathrm{p}$.

Hershey A.E., Fortino K., Peterson B.J. and Ulseth A.J., 2007. Stream Food Webs. Methods in Stream Ecology (Second Edition), chapter 27.

Hildrew A., 2009. Chapter 4 Sustained Research on Stream Communities: A Model System and The Comparative Approach. Advances in Ecological Research, 41, 175-312.

INS, 2009. National Institute of Statistics according to the Regional Thematic Analysis - Demographic evolution of the West Region, material provided by the West Regional Agency of Development (WRAD), Romania, 109 p. [in Romanian].

Jović A., Paunović M., Stojanović B., Milošević S. and Nikolić V., 2006. Aquatic invertebrates of the Ribnica and Lepenica rivers: composition of the community and water quality. Arch. Biol. Sci., 58, 115-119.

Kazanciand N. and Dügel M., 2008. Prediction of global climate change impact on structure of aquatic insect assemblages by using species optimum and tolerance values of temperature. Rev. Hydrobiol., 2, 73-80.

King A.J., Ward K.A., O'connor P., Green D., Tonkin Z.and Mahoney J., 2010. Adaptive management of an environmental watering event to enhance native fish spawning and recruitment. Fresh. Biol., $55,17-31$.

Kubosova K., Brabec K., Jarkovsky J. and Syrovatka V., 2010. Selection of indicative taxa for river habitats: a case study on benthic macroinvertebrates using indicator species analysis and the random forest methods. Hydrobiologia, 651, 101-114. 
Langheinrich U., Böhme D., Wegener U. and Lüderitz V., 2002. Streams in the Harz National Parks (Germany) - a hydrochemical and hydrobiological evaluation. Limnologica Ecology and Management of Inland Waters, 32, 309-321.

Li L., Zheng B. and Liu L., 2010. Biomonitoring and Bioindicators Used for River Ecosystems: Definitions, Approaches and Trends. Procedia Environmental Sciences, 2, 1510-1524.

Lukáš J. and Krno I., 2003. Caddisflies (Trichoptera) of the Gidra River Basin. Acta Zoologica Universitatis Comenianae, 45, 69-75.

Malicky H., 2008. The distribution of four morphotypes of Hydropsyche contubernalis McL. (Trichoptera, Hydropsychidae), a possible object for genetical studies on subspecific differentiation. Braueria, $35,41-42$.

Management Plan, 2007. Natura 2000 Management Plan - Mureş Lower Gorge and Lipovei Hills RO SPA0029 [in Romanian].

Management Plan, 2010. Natura 2000 Management Plan - Mureş Lower Gorge and Lipovei Hills RO SPA0029 [in Romanian].

Marcer A., Garcia V., Escobar A. and Pons X., 2010. Handling historical information on protectedarea systems and coverage. An information system for the Natura 2000 European context. Environmental Modelling \& Software, 25, 956-964.

Mobes-Hansen B. and Waringer J.A., 1998. The Influence of Hydraulic Stress on Microdistribution Patterns of Zoobenthos in a Sandstone Brook (Weidlingbach, Lower Austria). Internat. Rev. Hydrobiol., 83, 381-396.

Ohl C., Johst K., Meyerhoff J., Beckenkamp M., Grüsgen V. and Drechsler M., 2010. Long-term socioecological research (LTSER) for biodiversity protection - A complex systems approach for the study of dynamic human-nature interactions. Ecological Complexity, 7, 170-178.

Pastuchová Z., 2006. Macroinvertebrate assemblages in conditions of low-discharge streams of the Cerová vrchovina highland in Slovakia. Limnologica Ecology and Management of Inland Waters, 36, 241-250.

Paulsa S., Grafb W., Haasea P., Lumbschc T.H. and Waringer J., 2008. Grazers, shredders and filtering carnivores - The evolution of feeding ecology in Drusinae (Trichoptera: Limnephilidae): Insights from a molecular phylogeny. Molecular Phylogenetics and Evolution, 46, 776-791.

Pinto R., de Jonge V.N., Neto J.M., Domingos T., Marque J.C. and Patrício J., 2011. Towards a DPSIR driven integration of ecological value, water uses and ecosystem services for estuarine systems. Ocean \& Coastal Management, 30,1-16.

Pîrvu M., Pacioglu O., 2012. The ecological requirements of caddisflies larvae (Insecta: Trichoptera) and their usefulness in water quality assessment of a river in south-west Romania. Knowledge and Management of Aquatic Ecosystems, 407, 03.

Renöfält B.M., Jansson R. and Nilsson C., 2010. Effects of hydropower generation and opportunities for environmental flow management in Swedish riverine ecosystems. Fresh. Biol., 55, 49-67.

RSY, 2008. Romanian Statistical Yearbook according to the Regional Thematic Analysis - Demographic evolution of the West Region, material provided by the West Regional Agency of Development (WRAD), Romania, 109 p. [in Romanian].

Ruiz-García A.R., Márquez-Rodríguez J. and Ferreras-Romero M., 2012. Implications of anthropogenic disturbance factors on the Trichoptera assemblage in a Mediterranean fluvial system: Are Trichoptera useful for identifying land-use alterations? Ecological Indicators, 14, 114-123.

Savić A., Ranđelović V., Đorđević M., Karadžić B., Đokić M., Krpo-Ćetković J., 2013. The influence of environmental factors on the structure of caddisfly (Trichoptera) assemblage in the Nišava River (Central Balkan Peninsula). Knowledge and Management of Aquatic Ecosystems, 409, 03.

Schetke S., Haase D. and Kötter T., 2012. Towards sustainable settlement growth: A new multi-criteria assessment for implementing environmental targets into strategic urban planning. Environmental Impact Assessment Review, 32, 195-210.

Schmeraa D. and Erös T., 2011. The role of sampling effort, taxonomical resolution and abundance weight in multivariate comparison of stream dwelling caddisfly assemblages collected from riffle and pool habitats. Ecological Indicators, 11, 230-239.

Simanonok M.P., Anderson C.B., Pastur G.M., Lencinas M.V. and Kennedy J.H., 2011. A comparison of impacts from silviculture practices and North American beaver invasion on stream benthic macroinvertebrate community structure and function in Nothofagus forests of Tierra del Fuego. Forest Ecology and Management, 262, 263-269. 
Sîrbu I. and Benedek A.M., 2004. Practical ecology. L. Blaga University Press, Sibiu, Romania, 260 p. [in Romanian].

Stan G., 1995. Statistical methods with applications in entomological research. Bul. Inf. Soc. Lepid. Rom., 6, 67-96 [in Romanian].

Sundermann A., Pauls S.U., Clarke R.T. and Haase P., 2008. Within-stream variability of benthic invertebrate samples and EU Water Framework Directive assessment results. Fundamental and Applied Limnology, Archiv für Hydrobiologie, 173, 21-34.

Tamazian A., Chousa J.P. and Vadlamannati K.C., 2009. Does higher economic and financial development lead to environmental degradation: Evidence from BRIC countries. Energy Policy, 37, 246-253.

Thorp J.H. and Rogers D.C., 2011. Caddisflies: Insect Order Trichoptera. Field Guide to Freshwater Invertebrates of North America, Chap. 25.

Tisdell C., 2011. Biodiversity conservation, loss of natural capital and interest rates. Ecological Economics, 70, 2511-2515.

Tscherninga K., Helminga K., Krippnera B., Siebera S., Gomez S. and Gomez P., 2012. Does research applying the DPSIR framework support decision making? Land Use Policy, 29, 102-110.

TSEDA-TCC, 2009. Economic and social development strategy of Timiş County. Timiş Social and Economic Development Agency - Timiş County Council, Romania, 344 p. [in Romanian]

Varnosfaderany M.N., Ebrahimi E., Mirghaffary N. and Safyanian A., 2010. Biological assessment of the Zayandeh Rud River, Iran, using benthic macroinvertebrates. Limnologica - Ecology and Management of Inland Waters, 40, 226-232.

Velázquez J., Tejera R., Hernando A. and Núñez M.V., 2010. Environmental diagnosis: Integrating biodiversity conservation in management of Natura 2000 forest spaces. Journal for Nature Conservation, 18, 309-317.

Wallace I.D., 1990. A review of the Trichoptera of Great Britain. Research \& Survey in Nature Conservation, 32, 1-59.

Wallace I.D., Wallace B. and Philipson G.N., 2003. Case-bearing caddis larvae of Britain and Ireland. Freshwater Biological Association, UK, $308 \mathrm{p}$.

Waringer J. and Graf W., 1997. Atlas der Österreichischen Köcherfliegenlarven. Facultas Universitätsverlag, Wien, 320 p. [in German].

Wildsmith M.D., Rose T.H., Potter I.C., Warwick R.M. and Clarke K.R., 2011. Benthic macroinvertebrates as indicators of environmental deterioration in a large microtidal estuary. Marine Pollution Bulletin, $62,525-538$.

Winkelmann C., Worischka S., Koop J.H.E. and Benndorf J., 2007. Predation effects of benthivorous fish on grazing and shredding macroinvertebrates in a detritus-based stream food web. LimnologicaEcology and Management of Inland Waters, 37, 121-128.

WRAD, 2009. Regional thematic analysis - demographic evolution of the west region. West Regional Agency for Development, Romania, 109 p. [in Romanian].

Xing Y., Horner M.R.W., El-Haram M.A. and Bebbington J., 2009. A framework model for assessing sustainability impacts of urban development. Accounting Forum, 33, 209-224.

Yoshimura M., 2008. Longitudinal patterns of benthic invertebrates along a stream in the temperate forest in Japan: in relation to humans and tributaries. Insect Conservation and Diversity, 1, 95-107. 